\title{
Metastatic Ovarian Tumor of Vulvar Malignant Melanoma in a 43-Year-Old Woman: A Case Report and Literature Review
}

\author{
Yasuyuki Kawagoe ${ }^{*}$, Midori Fujisaki', Tomoko Goto', Noriko Ueno"1, Junji Onishi', \\ Kosuke Mochida ${ }^{2}$, Yuichiro Sato ${ }^{3}$, Hiroshi Sameshima ${ }^{1}$ \\ ${ }^{1}$ Department of Obstetrics and Gynecology, Faculty of Medicine, University of Miyazaki, Kihara, Kiyotake, Miyazaki, \\ Japan \\ ${ }^{2}$ Department of Dermatology, University of Miyazaki Hospital, Faculty of Medicine, University of Miyazaki, Kihara, Kiyotake, \\ Miyazaki, Japan \\ ${ }^{3}$ Department of Diagnostic Pathology, University of Miyazaki Hospital, Faculty of Medicine, University of Miyazaki, Kihara, \\ Kiyotake, Miyazaki, Japan \\ Email: *yasuyuki_kawagoe@med.miyazaki-u.ac.jp
}

How to cite this paper: Kawagoe, Y., Fujisaki, M., Goto, T., Ueno, N., Onishi, J., Mochida, K., Sato, Y. and Sameshima, H. (2021) Metastatic Ovarian Tumor of Vulvar Malignant Melanoma in a 43-Year-Old Woman: A Case Report and Literature Review. Open Journal of Obstetrics and Gynecology, 11, 1-11.

https://doi.org/10.4236/ojog.2021.111001

Received: December 10, 2020

Accepted: January 11, 2021

Published: January 14, 2021

Copyright $\odot 2021$ by author(s) and Scientific Research Publishing Inc. This work is licensed under the Creative Commons Attribution International License (CC BY 4.0).

http://creativecommons.org/licenses/by/4.0/ (c) (i) Open Access

\begin{abstract}
An ovarian malignant melanoma sometimes occurs from ovarian teratoma. Ovarian metastatic malignant melanoma is extremely rare. We describe a patient in whom vulvar melanoma (previously resected) metastasized to the ovary, making ovarian metastatic malignant melanoma. A 43-year-old Japanese woman was referred to us because of left ovarian tumor. She had undergone resection for malignant melanoma on the right labia minora with inguinal lymph node metastasis (pT1bN1aM0, stage IIIA, FIGO 2008). Eighteen months after this surgery, CT scans revealed left ovarian tumor and swelled pelvic lymph nodes, with a pelvic examination disclosing a left adnexal solid mass, with normal serum CA125 level $(21.7 \mathrm{U} / \mathrm{mL})$. Laparotomy revealed a left solid ovarian tumor measuring $4 \mathrm{~cm}$, which was covered with a smooth grayish capsule. The right ovary, uterus, and pelvic cavity appeared normal. Upon sectioning during the surgery, the cross-sectional surface of the left ovary revealed a dark brown solid tumor. Following an intra-operative frozen-section diagnosis as metastatic melanoma, total hysterectomy with bilateral salpingo-oophorectomy and pelvic lymph dissection was performed. Histological examination confirmed the diagnosis as malignant melanoma metastasis to the left ovary and the obturator lymph node: the same laterality (left) as the primary site. The tumor was entirely composed of malignant melanoma cells with no evidence of teratoma. Combined chemotherapy with dabrafenib mesylate and trametinib was planned based on the positive BRAF mutations. This case highlights the importance that physicians should have
\end{abstract}


high index of suspicion for the occurrence of ovarian melanoma metastasis after melanoma surgery. We also made extensive literature review on this issue, of which description may contribute to better understanding of this condition.

\section{Keywords}

Vulva, Malignant Melanoma, Ovarian Metastasis

\section{Introduction}

Primary ovarian melanoma is sporadic, and most cases originate within a mature cystic teratoma, while metastatic malignant melanoma of the ovary is a rare condition. Most commonly originates from cutaneous tumors, and sometimes from ocular melanoma. The vulva is the most common site of melanoma in the female genital tract, while only one case of vulvar melanoma metastasis to the ovary has been reported [1]. The median age at diagnosis of cutaneous melanoma in sun-exposed skin is 56 years, while that of the vulva is 68 years, but it rarely occurs in women of a reproductive age [2] [3]. We describe here an unusual case of a woman who underwent surgical removal of melanoma of the vulva at 41 years of age, and subsequently developed left ovarian metastasis 18 months after the initial surgery.

\section{Case Presentation}

A 43-year-old Japanese gravida 2 para 2 premenopausal woman was referred to our gynecological department because of significant enlargement of the left ovary. At 36 years of age, pigmentation of the external genitalia was detected at the time of her second delivery, although it was left untreated. Her past and family medical histories were uneventful. Five years after the delivery, when she was 41 years old, she noticed a slight bump on the surface of the pigmented skin accompanied by scant bleeding. She visited a local dermatological hospital, whereupon a gray-white irregular lesion was detected on the left labia minora, which was diagnosed as a malignant melanoma by biopsy. The patient then consulted the Department of Dermatology at the University Hospital. A darkly pigmented lesion was confirmed on the left labia minora measuring approximately $10 \mathrm{~mm}$ in size. The patient subsequently underwent radical local excision plus sentinel lymph node sampling. Pathologically, the nodular lesion was composed of polygonal cell proliferation with lesional melanin deposition (Figure 1(a)). The tumor cells were diffusely positive for HMB- 45 by immunohistochemical analysis. The thickness of the tumor was $3.5 \mathrm{~mm}$, and the width was $8 \mathrm{~mm}$, with no ulcer formation. With a positive sentinel lymph node result, the entire left inguinal lymph node was dissected a few weeks after the initial surgery. The final histological examination revealed a vulvar melanoma with inguinal lymph node 


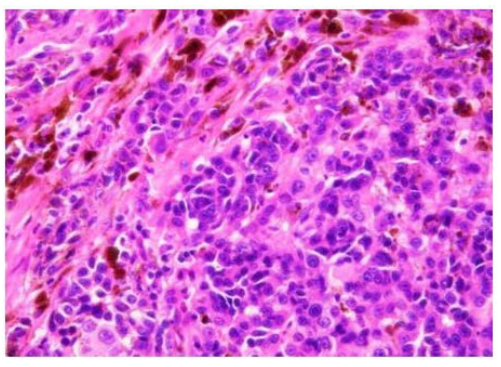

(a)

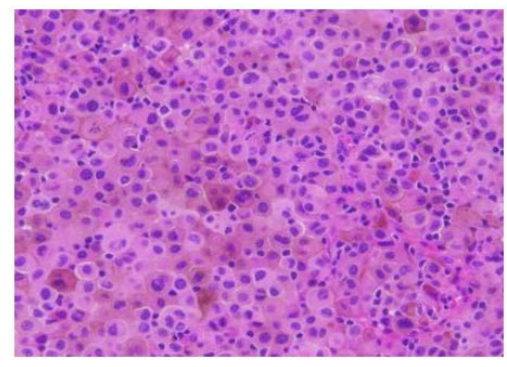

(b)

Figure 1. (a) Vulva: Polygonal tumor cells proliferate in nests or diffusely. Melanin pigments are also present; (b) Left ovary: Polygonal tumor cells with round to oval-shaped hyperchromatic nuclei and prominent nucleoli proliferatein sheets. Melanin deposition is also observed (Hematoxylin and eosin, $\times 400$ ).

metastasis (pT1bN1aM0, stage IIIA, FIGO 2008). No adjuvant therapy was initiated, and the patient continued to be regularly followed up.

Eighteen months after the surgery, CT scans taken at a routine medical examination revealed significant swelling of the left ovary and pelvic lymph nodes, compared with previous CT scans taken just before the surgery. After the reference to the gynecological department, pelvic examination disclosed a left adnexal solid mass, a normal-sized uterus and a right ovary. She had no symptoms or complaints on her first visit. Pelvic MRI (T-weighted image) also showed a low-intensity solid tumor of the left ovary measuring $35 \times 40 \mathrm{~mm}$ and significant enlargement of a pelvic lymph node (Figure 2). Serum CA125 level was 21.7 $\mathrm{U} / \mathrm{mL}$, which was within the normal range. At laparotomy, a left solid ovarian tumor covered with a smooth grayish and intact capsule was confirmed without adhesions to its surroundings (Figure 3). The right ovary, uterus, and pelvic cavity appeared grossly normal. The left obturator and external iliac lymph nodes were swollen. Infracolic-omentum and peritoneal surfaces were smooth with no evidence of dissemination. Upon sectioning, the cross-sectional surface of the left ovary showed characteristic findings of a homogenous dark brown solid tumor (Figure 4). The diagnosis of the intra-operative frozen section was metastatic malignant melanoma. Total hysterectomy with bilateral salpingo-oophorectomy and pelvic lymph dissection was performed. As a final diagnosis, metastases to both the left ovary and the obturator lymph node were determined histologically. The tumor was entirely composed of malignant melanoma cells with no evidence of teratoma, and peritoneal cytology was negative for atypical cells (Figure 1(b)). These metastatic lesions were evident only on the left side, which was on the same side as the primary lesion on the vulva. Her postoperative course was uneventful. Two months after surgery, combined chemotherapy with dabrafenib mesylate and trametinib was planned based on the positive results of molecular testing for $B R A F$ mutations.

\section{Discussion}

Incidence rates of malignant melanoma differ according to ethnic background, 


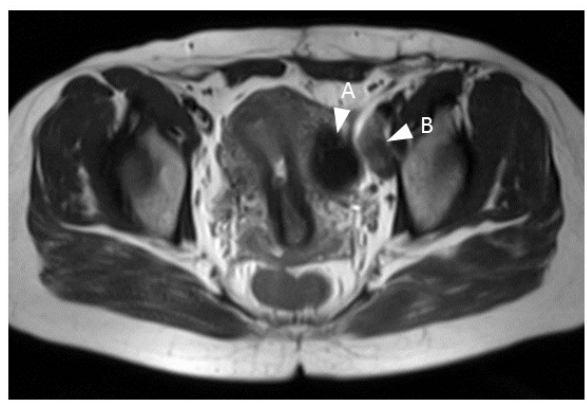

Figure 2. Pelvic MRI study (T2-weighted image) showed a low-intensity solidtumor of left ovary (arrow A) and significant enlargement of an obturator lymphnode (arrow B).

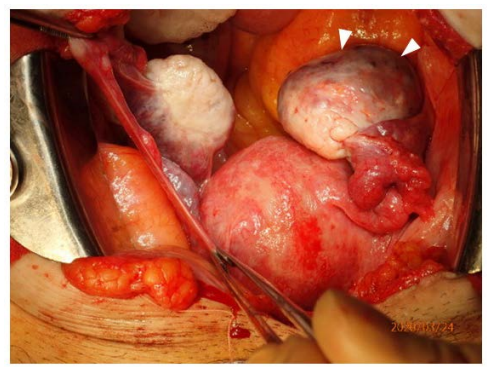

Figure 3. The left ovary was palpable about $40 \times 35 \mathrm{~mm}$ (arrows), covered with the grayish surface, while the right ovary and uterus were grossly normal appearance.

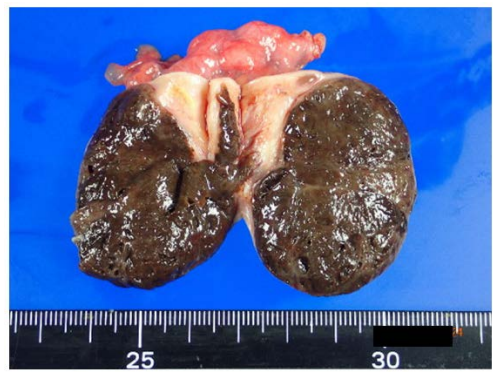

Figure 4. The cross-sectional surface of the left ovary showed a solid tumor colored in dark brown.

and the incidence rate was 24.9 in White, 1.3 in Asian/Pacific Islander, and 1.0 in black individuals per 100,000 between 2012 and 2016 [4]. Melanoma commonly arises from cutaneous sites in regions exposed to ultraviolet radiation. Extracutaneous sites lined with mucosal membranes can also include an original site of melanoma such as the respiratory, gastrointestinal, and urogenital tracts. Vulvar melanoma is a mucosal type as well, which is rare and is more aggressive. It usually results in less favorable prognoses compared with cutaneous melanoma.

Malignant melanoma in the ovary can involve either a primary or metastatic tumor, but most cases are metastatic [5]. Primary ovarian melanoma is sporadic, and most cases originate within a mature cystic teratoma. Metastases of melanoma to the ovary occur from the skin, and choroid of the eye, but rarely from primary vulva tumors, the prognosis of which is poor with a 5-year survival rate of only $5 \%$ [6]. In postmortem cases, approximately $18 \%$ of women with disse- 
minated melanoma have ovarian implants [7]. Taken together, it is conceivable that our case was vulvar melanoma in a woman of reproductive age, resulting in metastasis to the ovary. Both findings are extremely unusual phenomena.

We searched PubMed and Google Scholar, from January 1980 to December 2019, using the terms "ovary/ovarian"; "melanoma"; and "metastatic/metastasis/ metastases". The literature was limited to English-language case reports and case series. They comprised four case series [5] [8] [9] [10] and 22 case reports [1] [6] [11]-[30], totaling 61 cases. We excluded cases that met any of the following criteria: no medical information available; metastases confirmed at autopsy; and unknown original site of melanoma. Forty-one out of the 61 cases plus our case, totaling 42 cases, were available for this review and are listed in Table 1 [1] [5] [6] [8] [10]-[27] [29] [30]. Based on this search, this is the second report of ovarian metastasis of vulvar melanoma. The most frequent primary site was the skin $(83.3 \%, 35 / 42)$ followed by the choroid $(11.9 \%, 5 / 42)$, while two cases were from the vulva $(4.8 \%, 2 / 42)$. The median age at ovarian metastasis was 38.5 years (range, 8 - 65 years), and $85.7 \%$ (36/42) of patients were less than 50 years old. The median interval for relapse was 66 months (range, 8 - 300). The median tumor size was $100 \mathrm{~mm}$ (range, $40-190 \mathrm{~mm}$ ), and bilateral ovaries were affected in $26.8 \%(11 / 41)$ of cases. In deceased patients $(n=27)$, the median survival period after the confirmation of ovarian metastasis was 10 months (range, 1 - 96).

In an analysis of 1521 cases of melanoma, which included male patients, the most frequent site of first metastasis was the lung, followed by the skin, and lymph nodes, and $14 \%$ of cases had multiple metastatic sites [31]. Our review showed that $81.0 \%(34 / 42)$ of the cases involved multiple lesions when ovarian implants were identified, while this was rare for solitary metastasis. Once ovarian metastasis had established, extensive multisystemic spread of the disease occurred in most cases.

In patients in which an ovarian tumor is detected long after the initial treatment, it is a diagnostic challenge. Therefore, for patients with such a history, a precise medical interview is essential, and systemic screening is mandatory. In our case, routine CT scans allowed for the discovery of a unilateral ovarian tumor of a relatively small size. We were able to classify metastatic sites without difficulty because of the short interval since the last surgery. As such, regular screening could contribute to the early detection of metastases. However, this does not always lead to a preferred prognosis because most cases are accompanied by multiple metastatic lesions, resulting in a survival period of less than 1 year after relapse. It is interesting to note that the interval for ovarian metastasis was long, at 5 years or more in $64.2 \%$ (27/42) of cases, and 10 years or more in $23.8 \%(10 / 42)$ of cases. Especially, metastases from choroidal melanoma tend to have a latent period than metastasis from cutaneous melanoma. In most cases, it was associated with multiple metastases. At the initial therapy for melanoma, it is crucial to inform patients and their families about the possibility of relapse after a long period. 
Table 1. Published cases of metastatic malignant melanoma to the ovary $(n=42)$.

\begin{tabular}{|c|c|c|c|c|c|c|c|c|c|c|}
\hline $\begin{array}{l}\text { Author (year) } \\
\text { [Reference] }\end{array}$ & $\begin{array}{l}\text { Case } \\
\text { No. }\end{array}$ & $\begin{array}{c}\text { Age } \\
\text { (years) }\end{array}$ & $\begin{array}{c}\text { Primary } \\
\text { site }\end{array}$ & $\begin{array}{l}\text { Laterality } \\
\text { of the } \\
\text { affected } \\
\text { ovary }\end{array}$ & $\begin{array}{c}\text { Size of } \\
\text { ovarian } \\
\text { tumor } \\
(\mathrm{mm})\end{array}$ & $\begin{array}{c}\text { Clinical } \\
\text { symptoms }\end{array}$ & $\begin{array}{c}\text { Extent } \\
\text { disease } \\
\text { adimitted }\end{array}$ & $\begin{array}{c}\text { Other } \\
\text { sites of } \\
\text { metastasis }\end{array}$ & $\begin{array}{l}\text { Interval } \\
\text { from } \\
\text { primary } \\
\text { (months) }\end{array}$ & $\begin{array}{l}\text { Outcome } \\
\text { (time after } \\
\text { surgery) }\end{array}$ \\
\hline \multirow[t]{5}{*}{$\begin{array}{l}\text { Fitzgibbons PL } \\
\text { (1987) [8] }\end{array}$} & 1 & 38 & skin (scalp) & Bil & 80 & NA & Yes & axillary LN & 48 & NA \\
\hline & 2 & 45 & skin (thumb) & Uni & NA & NA & No & & 24 & Died (12 Mo) \\
\hline & 3 & 32 & skin (leg) & Uni & 180 & NA & Yes & chest wall & 60 & NA \\
\hline & 4 & 37 & skin (leg) & Bil & NA & NA & Yes & $\begin{array}{c}\text { lung, } \\
\text { omentum }\end{array}$ & 60 & NA \\
\hline & 5 & 29 & skin (arm) & Bil & 120 & NA & Yes & axillary LN & 24 & NA \\
\hline \multirow[t]{3}{*}{$\begin{array}{l}\text { Moselhi M } \\
\text { (1998) [10] }\end{array}$} & 6 & 36 & skin (leg) & Uni & 100 & pelvic pain & No & & 96 & Died (NA) \\
\hline & 7 & 25 & skin (leg) & Bil & 80 & $\begin{array}{c}\text { regular } \\
\text { screening }\end{array}$ & Yes & $\begin{array}{l}\text { large bowel } \\
\text { mesentery }\end{array}$ & 24 & Died (NA) \\
\hline & 8 & 45 & skin (arm) & Uni $^{*}$ & 80 & $\begin{array}{l}\text { abdominal } \\
\text { bloating }\end{array}$ & Yes & $\begin{array}{l}\text { pelvic bone, } \\
\text { lung }\end{array}$ & 24 & Died (NA) \\
\hline \multirow[t]{12}{*}{$\begin{array}{l}\text { Gupta D } \\
(2004)[5]\end{array}$} & 9 & 29 & $\begin{array}{c}\text { skin } \\
\text { (shoulder) }\end{array}$ & Uni & 110 & regular screening & Yes & multiple & 15 & Died (10 Mo) \\
\hline & 10 & 39 & skin (arm) & Bil & 70 & regular screening & Yes & multiple & 120 & Died (26 Mo) \\
\hline & 11 & 25 & skin (back) & Uni & 135 & $\begin{array}{c}\text { dysuria, } \\
\text { abdominal pain }\end{array}$ & Yes & $\begin{array}{c}\text { para-aortic } \\
\text { LN }\end{array}$ & 96 & Died (32 Mo) \\
\hline & 12 & 29 & skin (back) & Uni & 150 & regular screening & Yes & multiple & 34 & Died (40 Mo) \\
\hline & 13 & 43 & skin (arm) & Uni & 100 & pelvic mass & Yes & multiple & 132 & Died (7 Mo) \\
\hline & 14 & 45 & skin (arm) & Uni & 180 & regular screening & Yes & $\begin{array}{l}\text { lungs, } \\
\text { abdominal } \\
\text { wall }\end{array}$ & 228 & Died (4 Mo) \\
\hline & 15 & 49 & skin (arm) & Uni & 55 & pelvic mass & Yes & $\begin{array}{l}\text { lungs, } \\
\text { perirectal } \\
\text { mass }\end{array}$ & 20 & Died (8 Mo) \\
\hline & 16 & 40 & skin (arm) & Uni & 60 & regular screening & Yes & multiple & 30 & Died (30 Mo) \\
\hline & 17 & 41 & $\begin{array}{c}\text { skin } \\
\text { (shoulder) }\end{array}$ & Uni & 100 & regular screening & Yes & multiple & 83 & Died (76 Mo) \\
\hline & 18 & 38 & skin (pubis) & Uni & 120 & regular screening & Yes & lungs & 74 & Alive (96 Mo) \\
\hline & 19 & 27 & $\begin{array}{c}\text { skin } \\
\text { (shoulder) }\end{array}$ & Uni & 80 & regular screening & Yes & axillary LN & 46 & Alive (6 Mo) \\
\hline & 20 & 52 & skin (scalp) & Uni & 50 & regular screening & Yes & multiple & 54 & Died (10 Mo) \\
\hline $\begin{array}{l}\text { Murphy DJ } \\
\text { (1994) [11] }\end{array}$ & 21 & 25 & skin (scalp) & Bil & 120 & regular screening & Yes & $\begin{array}{c}\text { axillary LN, } \\
\text { subcutaneous } \\
\text { tissue }\end{array}$ & 26 & NA \\
\hline $\begin{array}{l}\text { Remadi S } \\
\text { (1997) [12] }\end{array}$ & 22 & 33 & skin (chest) & Uni & 100 & abdominal pain & No & & 60 & Died (24 Mo) \\
\hline $\begin{array}{c}\text { Nakano J } \\
(1998)[13]\end{array}$ & 23 & 36 & skin (arm) & Bil & 125 & $\begin{array}{l}\text { pelvic pain, } \\
\text { multiple } \\
\text { subcutaneous } \\
\text { nodules }\end{array}$ & Yes & subcutaneus & 132 & Died (13 Mo) \\
\hline
\end{tabular}




\begin{tabular}{|c|c|c|c|c|c|c|c|c|c|c|}
\hline $\begin{array}{c}\text { Piura B } \\
(1998)[14]\end{array}$ & 24 & 45 & skin (back) & Uni & 100 & $\begin{array}{l}\text { abdominal pain, } \\
\text { pelvic mass }\end{array}$ & Yes & $\begin{array}{l}\text { subcutaneus } \\
\text { tissue, brain }\end{array}$ & 84 & Alive (7 Mo) \\
\hline $\begin{array}{l}\text { Fuller PN } \\
(1999)[15]\end{array}$ & 25 & 34 & skin (arm) & Bil & 190 & abdominal pain & Yes & brain & 180 & Died (1 Mo) \\
\hline $\begin{array}{c}\text { Bilgin T } \\
(2000)[16]\end{array}$ & 26 & 35 & skin (scalp) & Bil & 94 & $\begin{array}{l}\text { abdominal } \\
\text { bloating }\end{array}$ & Yes & $\begin{array}{l}\text { omentum, } \\
\text { liver }\end{array}$ & 96 & Died (5 Mo) \\
\hline $\begin{array}{c}\text { Oliver R } \\
(2005)[17]\end{array}$ & 27 & 58 & skin (arm) & Uni & 120 & asymptomatic & Yes & pelvic LN & 120 & Died (12 Mo) \\
\hline $\begin{array}{l}\text { Boutis A } \\
(2008)[18]\end{array}$ & 28 & 43 & skin (arm) & Uni $^{*}$ & NA & $\begin{array}{l}\text { abdominal } \\
\text { distension }\end{array}$ & Yes & $\begin{array}{l}\text { peritnium, } \\
\text { omentum }\end{array}$ & 108 & Died (8 Mo) \\
\hline $\begin{array}{c}\text { Abe Y } \\
(2009)[19]\end{array}$ & 29 & 39 & skin (leg) & Uni & 65 & $\begin{array}{l}\text { abdominal } \\
\text { fullness, } \\
\text { appetite loss }\end{array}$ & Yes & iliac bone & 8 & Died (7 Mo) \\
\hline $\begin{array}{c}\text { Sbitti Y } \\
(2011)[20]\end{array}$ & 30 & 45 & skin (leg) & Uni & 150 & pelvic pain & No & & 38 & Died (13 Mo) \\
\hline $\begin{array}{c}\text { Fenzl V } \\
(2011)[21]\end{array}$ & 31 & 35 & skin (back) & Bil & 90 & $\begin{array}{l}\text { acute abdomen, } \\
\text { fever, } \\
\text { appetite loss }\end{array}$ & Yes & bone & 60 & Died (15 Mo) \\
\hline $\begin{array}{l}\text { Habek D } \\
\text { (2012) [22] }\end{array}$ & 32 & 35 & skin (back) & Uni & 110 & abdominal pain & Yes & brain & 84 & Died (3 Mo) \\
\hline $\begin{array}{c}\text { Berisavac M } \\
(2013)[23]\end{array}$ & 33 & 48 & skin (arm) & Uni & 125 & abdominal pain & No & & 60 & Died (48 Mo) \\
\hline $\begin{array}{c}\text { Araki Y } \\
(2014)[24]\end{array}$ & 34 & 8 & $\begin{array}{c}\text { skin } \\
\text { (buttock) }\end{array}$ & Uni & 60 & regular screening & Yes & liver, bone & 8 & Died (14 Mo) \\
\hline $\begin{array}{l}\text { Mendel A } \\
\text { (2017) [6] }\end{array}$ & 35 & 65 & skin (leg) & Uni & 76 & regular screening & Yes & $\begin{array}{l}\text { liver, spleen, } \\
\text { esphagus, } \\
\text { lung }\end{array}$ & 84 & NA \\
\hline $\begin{array}{c}\text { Ben David M } \\
\text { (1984) [25] }\end{array}$ & 36 & 62 & choroid & Uni & 150 & $\begin{array}{l}\text { abdominal pain, } \\
\text { vaginal bleeding }\end{array}$ & Yes & $\begin{array}{l}\text { lung, } \\
\text { omentum, } \\
\text { serosal } \\
\text { surface of } \\
\text { small and } \\
\text { large bowel }\end{array}$ & 300 & NA \\
\hline $\begin{array}{c}\text { Santeusanio G } \\
(2000)[26]\end{array}$ & 37 & 47 & choroid & Uni & 170 & pelvic pain & No & & 168 & NA \\
\hline $\begin{array}{l}\text { Rey-Caballero } \\
\text { VE (2004) [27] }\end{array}$ & 38 & 38 & choroid & Uni & 61 & abdominal pain & No & & 108 & Alive (7 Mo) \\
\hline $\begin{array}{c}\text { Bloch-Marcotte } \\
\text { C (2008) [29] }\end{array}$ & 39 & 50 & choroid & Uni & 40 & abdominal pain & Yes & liver & 240 & Alive (5 Mo) \\
\hline $\begin{array}{c}\text { Mandato VD } \\
(2010)[30]\end{array}$ & 40 & 57 & choroid & Bil & 110 & $\begin{array}{l}\text { hypogastric pain, } \\
\text { weight loss }\end{array}$ & Yes & $\begin{array}{c}\text { pancreas, } \\
\text { para-aortic } \\
\text { LN }\end{array}$ & 72 & Died (7 Mo) \\
\hline $\begin{array}{l}\text { Spatz A } \\
(1999)[1]\end{array}$ & 41 & 28 & $\begin{array}{c}\text { vulva } \\
\text { (labia majora) }\end{array}$ & Uni & 65 & regular screening & No & & 180 & Alive (12 Mo) \\
\hline $\begin{array}{l}\text { Kawagoe } \\
\mathrm{Y}(2020)\end{array}$ & 42 & 43 & $\begin{array}{c}\text { vulva } \\
\text { (labia minora) }\end{array}$ & Uni & 50 & regular screening & Yes & obturator LN & 18 & Alive (4 Mo) \\
\hline
\end{tabular}

${ }^{\star}$ Laterality was determined by CT imaging without operation. ${ }^{* *}$ Tumor sizes are expressed by the maximum dimension. LN: lymph node, NA: Not available, Mo: month, Uni: Unilateral, Bil; Bilateral. 
The ovary is a small organ in the pelvis and is a relatively common site of metastases. This has been speculated to be as a result of its hypervascularity [32] [33]. Ovarian metastases are thought to mainly occur in reproductive-age women, and less frequently in postmenopausal women. Our review showed that the median age of diagnosis was 38.5 years and $85.7 \%$ of patients were less than 50 years old, even though melanoma is common in older adults.

Ovarian metastases are typically from the stomach, colon, and breast. These metastatic lesions in the ovary are known to show bilateral and multicystic lesions, namely mucinous carcinoma, compared with primary lesions. Our patient had a solid homogenous unilateral tumor, the cross-section of which was dark brown. This was the first case in which we had observed such characteristics of metastatic melanoma. Its entire capsule was also a grayish color with a smooth surface. Young et al. reported in a review of ovarian metastases that $55 \%$ of the tumors were solid, while $45 \%$ were solid and cystic with the solid component predominating. Thirty percent of the tumors were either entirely black or had discernible black or brown foci [9]. Gupta et al. reported that 35\% of the lesions were grossly pigmented [5]. Regarding laterality, bilateral involvement was commonly seen in cutaneous melanoma in $45 \%$ of cases [9]. In our review, which included choroidal and vulvar melanoma, its incidence was less frequent at $26.8 \%$.

\section{Conclusion}

We here described the second reported case of ovarian metastasis of vulvar melanoma in a 43-year-old woman. In patients who have a history of melanoma and a significant enlargement of the ovary, metastasis should be ruled out. Metastasis usually occurs after a long period and accompanies disseminated disease, resulting in a poor prognosis of generally less than 1-year survival.

\section{Consent}

Informed consent was obtained.

\section{Conflicts of Interest}

The authors have no conflicts of interest relevant to this article.

\section{References}

[1] Spatz, A., Zimmermann, U., Bachollet, B., Pautier, P., Michel, G. and Duvillard, P. (1998) Malignant Blue Nevus of the Vulva with Late Ovarian Metastasis. The American Journal of Dermatopathology, 20, 408-412. https://doi.org/10.1097/00000372-199808000-00016

[2] Ragnarsson-Olding, B., Johansson, H., Rutqvist, L. and Ringborg, U. (1993) Malignant Melanoma of the Vulva and Vagina. Trends in Incidence, Age Distribution, and Long-Term Survival among 245 Consecutive Cases in Sweden 1960-1984. Cancer, 71, 1893-1897.

https://doi.org/10.1002/1097-0142(19930301)71:5<1893::AID-CNCR2820710528>3. 
$\underline{0 . \mathrm{CO} ; 2-7}$

[3] Sugiyama, V.E., Chan, J.K., Shin, J.Y., Berek, J.S., Osann, K. and Kapp, D.S. (2007) Vulvar Melanoma: A Multivariable Analysis of 644 Patients. Obstetrics \& Gynecology, 110, 296-301. https://doi.org/10.1097/01.AOG.0000271209.67461.91

[4] Centers for Disease Control and Prevention (2019) Melanoma Incidence and Mortality, United States 2012-2016. USCS Data Brief, No. 9. Centers for Disease Control and Prevention, US Department of Health and Human Services, Atlanta.

https://www.cdc.gov/cancer/uscs/about/data-briefs/no9-melanoma-incidence-mort ality-UnitedStates-2012-2016.htm

[5] Gupta, D., Deavers, M.T., Silva, E.G. and Malpica, A. (2004) Malignant Melanoma involving the Ovary: A Clinicopathologic and Immunohistochemical Study of 23 Cases. The American Journal of Surgical Pathology, 28, 771-780. https://doi.org/10.1097/01.pas.0000126786.69232.55

[6] Mendel, A., Terzibachian, J.J., Aubin, F. and Malicenco, L. (2017) Ovarian Metastasis of a Malignant Melanoma: A Case Report. Journal of Gynecology Obstetrics and Human Reproduction, 46, 461-462. https://doi.org/10.1016/j.jogoh.2017.02.016

[7] Das Gupta, T.K. and Brasfield, R.D. (1969) Primary Melanomas in Unusual Sites. Surgery, Gynecology and Obstetrics, 128, 841-848.

[8] Fitzgibbons, P.L., Martin, S.E. and Simmons, T.J. (1987) Malignant Melanoma Metastatic to the Ovary. The American Journal of Surgical Pathology, 11, 959-964. https://doi.org/10.1097/00000478-198712000-00006

[9] Young, R.H. and Scully, R.E. (1991) Malignant Melanoma Metastatic to the Ovary. A Clinicopathologic Analysis of 20 Cases. The American Journal of Surgical Pathology, 15, 849-860. https://doi.org/10.1097/00000478-199109000-00005

[10] Moselhi, M., Spencer, J. and Lane, G. (1998) Malignant Melanoma Metastatic to the Ovary: Presentation and Radiological Characteristics. Gynecologic Oncology, 69, 165-168. https://doi.org/10.1006/gyno.1998.4992

[11] Murphy, D.J., Hickling, D.J. and Pathak, U.N. (1994) Metastatic Malignant Melanoma of the Ovary. Case Report. European Journal of Gynaecological Oncology, 2, 119-120.

[12] Remadi, S., McGee, W., Egger, J.F. and Ismail, A. (1997) Ovarian Metastatic Melanoma. A Diagnostic Pitfall in Histopathologic Examination. Archives D'anatomie et de Cytologie Pathologiques, 45, 43-46.

[13] Nakano, J., Shimizu, T., Hirota, T. and Muto, M. (1998) An Unusual Female Melanoma Patient with Late Metastases to Both Skin and Ovaries. The Journal of Dermatology, 25, 126-128. https://doi.org/10.1111/j.1346-8138.1998.tb02363.x

[14] Piura, B., Kedar, I., Ariad, S., Meirovitz, M. and Yanai-Inbar, I. (1998) Malignant Melanoma Metastatic to the Ovary. Gynecologic Oncology, 68, 201-205. https://doi.org/10.1006/gyno.1997.4919

[15] Fuller, P.N. (1999) Malignant Melanoma of the Ovary and Exposure to Clomiphene Citrate: A Case Report and Review of the Literature. American Journal of Obstetrics and Gynecology, 180, 1499-1503. https://doi.org/10.1016/S0002-9378(99)70045-1

[16] Bilgin, T. (2000) Late Ovarian Metastases of a Cutaneous Malignant Melanoma. Journal of Obstetrics and Gynaecology, 20, 323. https://doi.org/10.1080/01443610050009791

[17] Oliver, R., Dasgupta, C., Coker, A., Al-Okati, D. and Weekes, A.R.L. (2005) Ovarian Malignant Melanoma: Unusual Presentation of a Solitary Metastasis. Gynecologic Oncology, 99, 412-414. https://doi.org/10.1016/j.ygyno.2005.06.066 
[18] Boutis, A., Valeri, R., Korantzis, I., Valoukas, D., Andronikidis, I. and Andreadis, C. (2008) Delayed Malignant Melanoma Recurrence Simulating Primary Ovarian Cancer: Case Report. World Journal of Surgical Oncology, 6, 124. https://doi.org/10.1186/1477-7819-6-124

[19] Abe, Y., Takeuchi, M., Matsuzaki, K., Uehara, H., Furumoto, H. and Nishitani, H. (2009) A Case of Metastatic Malignant Melanoma of the Ovary with a Multilocular Cystic Appearance on MR Imaging.Japanese Journal of Radiology, 27, 458-461. https://doi.org/10.1007/s11604-009-0368-6

[20] Sbitti, Y., Fadoukhair, Z., Kadiri, H., Oukabli, M., Essaidi, I., Kharmoum, S., M'rabti, H., Albouzidi, A., Ichou, M. and Errihani, H. (2011) Diagnostic Challenge for Ovarian Malignant Melanoma in Premenopausal Women: Primary or Metastatic? World Journal of Surgical Oncology, 9, Article No. 65.

https://doi.org/10.1186/1477-7819-9-65

[21] Fenzl, V., Prkacin, I. and Skrtic, A. (2011) Malignant Melanoma Ovarian Metastasis Mimicking Acute Tuboovarian Abscess. European Journal of Gynaecological Oncology, 32, 582-584. https://doi.org/10.2478/s11536-011-0133-y

[22] Habek, D., Marton, I., Bauman, R., Prka, M. and Bobic, M.V. (2012) Ruptured Ovarian Metastatic Malignant Melanoma Caused Acute Abdomen. Central European Journal of Medicine, 7, 241-244.

[23] Berisavac, M., Kotlica, B.K., Pilic, I. and Atanackovic, J. (2013) Metastatic Malignant Ovarian Melanoma-A Case Report. Vojnosanitetski Pregled, 70, 229-232. https://doi.org/10.2298/VSP110719030B

[24] Araki, Y., Kaneda, H., Oashi, K., Okada, S. and Tsutsumida, A. (2014) Ovarian Metastasis of Malignant Melanoma: The First Pediatric Case. Journal of Pediatric Surgery Case Reports, 2, 473-475. https://doi.org/10.1016/j.epsc.2014.09.010

[25] Ben David, M., Feldberg, D., Dicker, D., Kessler, H. and Goldman, J.A. (1984) Ovarian Melanoma: An Interesting Case. International Journal of Gynecology \& Obstetrics, 22, 77-79. https://doi.org/10.1016/0020-7292(84)90107-3

[26] Santeusanio, G., Ventura, L., Mauricello, A., Carosi, M., Spagnoli, L.G., Maturo, P., Terranova, L. and Romanini, C. (2000) Isolated Ovarian Metastasis from a Spindle Cell Malignant Melanoma of the Choroid 14 Years after Enucleation: Prognostic Implication of the Keratin Immunophenotype. Applied Immunohistochemistry \& Molecular Morphology, 8, 329-333. https://doi.org/10.1097/00022744-200012000-00011

[27] Rey-Caballero, V.E., Lopez-Gonzalez, B., Garcia-Benitez, J.L., Boix-Fos, A. and Diaz-Lagama, A.M. (2004) Solitary Ovarian Metastasis from Ocular Melanoma. American Journal of Obstetrics and Gynecology, 191, 368-369. https://doi.org/10.1016/j.ajog.2003.10.713

[28] Coutts, M.A., Borthwick, N.J., Hungerford, J.L. and Cree, I.A. (2006) Post-Menopausal Bleeding: A Rare Presentation of Metastatic Uveal Melanoma. Pathology Oncology Research, 12, 184-187. https://doi.org/10.1007/BF02893367

[29] Bloch-Marcotte, C., Ambrosetti, D., Novellas, S., Caramella, T., Dahman, M., Thyss, A. and Chevallier, P. (2008) Ovarian Metastasis from Choroidal Melanoma. Clinical Imaging, 32, 318-320. https://doi.org/10.1016/j.clinimag.2008.04.001

[30] Mandato, V.D., Kobal, B., Di Stefano, A., Sinkovec, J., Levicnik, A., La Sala, G.B. and Rakar, S. (2010) Choroidal Melanoma Metastasized to the Ovary: Case Report and Review of the Literature. European Journal of Gynaecological Oncology, 31, 109-113.

[31] Barth, A., Wanek, L.A. and Morton, D.L. (1995) Prognostic Factors in 1,521 Mela- 
noma Patients with Distant Metastases. Journal of the American College of Surgeons, 181, 193-201.

[32] Young, R.H. and Scully, R.E. (1991) Metastatic Tumors in the Ovary: A Problem-Oriented Approach and Review of the Recent Literature. Seminars in Diagnostic Pathology, 8, 250-276.

[33] Singh, N., (2004) The Pathology of Metastasis in the Ovary. Journal of Gynecologic Oncology, 9, 96-102. 